\title{
Accelerated Aging as a Vigor Test in Encholirium spectabile Seeds
}

\author{
Ariana Veras de Araújo $^{1}$ (D), Monalisa Alves Diniz da Silva ${ }^{2}$, \\ André Pereira Freire Ferraz ${ }^{3}$ (1) \\ ${ }^{1}$ Universidade Federal do Ceará (UFC), Fortaleza, CE, Brasil \\ ${ }^{2}$ Universidade Federal Rural de Pernambuco/Unidade Acadêmica de Serra Talhada (UFRPE/UAST) \\ ${ }^{3}$ Universidade Federal do Mato Grosso (UFMT), Rondonópolis, MT, Brasil
}

\begin{abstract}
The objective was to verify how differences in the accelerated aging test, traditional method (water) or saturated $\mathrm{NaCl}$ solution influence the differentiation of the physiological potential of Encholirium spectabile seeds from two geographic regions of Brazil (Graça-CE and Serra Talhada-PE). The experimental design was completely randomized in a $2 \times 2 \times 5$ factorial scheme, in which two methods (water and saturated $\mathrm{NaCl}$ solution), seeds from two geographic regions and five aging periods ( $0 \mathrm{~h}, 24 \mathrm{~h}, 48 \mathrm{~h}, 72 \mathrm{~h}$ and $96 \mathrm{~h}$ ) were evaluated. Results indicated that seeds from Graça-CE were less vigorous than those from Serra Talhada-PE. However, both aging methods (water and saturated $\mathrm{NaCl}$ solution) increased the physiological potential of seeds harvested from Graça-CE. E. spectabile seeds presented different levels of physiological potential by the accelerated aging test.
\end{abstract}

Keywords: Bromeliaceae, physiological conditioning, seed deterioration. 


\section{INTRODUCTION AND OBJECTIVES}

Studies on the applicability of methods for the evaluation of the physiological potential in bromeliaceous seeds deserve attention, due to the importance attributed to numerous species of this family. Among them, the Encholirium spectabile Mart. ex Schult. \& Schult. f., a native species belonging to the Bromeliaceae family, subfamily Pitcairnioideae, is popularly known in Brazil as "macambira-de-flecha" (Oliveira et al., 2013).

This species is propagated by seeds, and knowledge about its physiological performance is valuable because the species E. spectabile presents potential to be explored commercially for ornamental purposes and its medicinal characteristics, associated with the presence of phenolic compounds that activate cytoprotective mechanisms (Carvalho et al., 2010). In addition, the species is used in ruminant feeding in the Brazilian semi-arid region, especially during the dry season (Bessa, 1982; Lima, 1996).

It is also worth noting the high potential of the species for soil conservation, considering that the species forms clumps and its roots can act by holding the soil and preventing erosion. Even if its sustainable exploration is not immediate, the lack of knowledge of its potential use, together with the rapid and disorderly occupation of the semi-arid region of the Brazilian Northeast, may accelerate the species depletion.

The accelerated aging test is one of the most sensitive and efficient evaluations of seed vigor for several species and has been improved by several researchers (Marcos Filho, 2015). This test is based on the fact that the seed deterioration rate is increased by its exposure to high temperature and relative humidity (RH). Seeds with low vigor present a greater reduction of their viability when submitted to such stressful situations, whereas more vigorous seeds are less affected and show a relatively higher germination, even when subjected to the aging test (Marcos Filho, 1999).

The interaction between temperature and seed exposure time during the aging test are crucial factors for the assay efficiency, but for many species, this interaction has yet to be established (Guedes et al., 2011). Another factor to consider is the difference in the amount of water absorbed by the seeds when exposed to high humidity, especially when evaluated seeds are small, since they absorb water rapidly, intensifying the deterioration process (Alves \& Sá, 2012). For these reasons, the accelerated aging test has been performed using saturated mineral solutions $(\mathrm{NaCl}, \mathrm{KCl}$ and $\mathrm{NaBr})$ in replacement of water to delay the effects caused by rapid absorption of water by small seeds.

In Lactuca sativa L. and Cichorium intybus L. seeds, accelerated aging with saline $\mathrm{NaCl}$ solution for $48 \mathrm{~h}$ and $72 \mathrm{~h}$, respectively, was efficient in differentiating vigor levels (Santos et al., 2011). Alves et al. (2012) also demonstrated that the accelerated aging test with saturated $\mathrm{NaCl}$ solution at $41{ }^{\circ} \mathrm{C}$ for $48 \mathrm{~h}$ was a promising option for evaluating the physiological potential of Solanum gilo Raddi seeds.

The applicability of the accelerated aging test in assessing the physiological potential of native species seeds was verified in Copaifera langsdorffi $i$ Desf. (Ferreira et al., 2004), Anadenanthera colubrina (Vellozo) Brenan (Garcia et al., 2004), Dictyoloma vandellianum Adr. Juss. (Flavio \& Paula, 2010), Dalbergia nigra (Vell.) Fr. All. (Guedes et al., 2011), Myracrodruon urundeuva Allemão (Araújo et al., 2013), Chorisia glaziovii (O. Kuntze) (Guedes et al., 2013) and Poincianella pyramidalis (Tul.) LP Queiroz (Lima et al., 2014), for example. However, there are still few studies that contemplate seeds of native species in the face of the existing diversity.

Thus, the objective of this study was to verify how the accelerated aging test, a traditional method with water or saturated $\mathrm{NaCl}$ solution, influences the differentiation of the physiological potential of E. spectabile seeds from two geographic regions (Graça-CE and Serra Talhada-PE).

\section{MATERIALS AND METHODS}

\subsection{Collection and processing of seeds}

E. spectabile dried fruit stems were collected from 10 matrices randomly selected in two geographic regions, one located in the city of Graça, Ceará state ( $4^{\circ} 02^{\prime} 48^{\prime \prime}$ S and $40^{\circ} 44^{\prime} 59^{\prime \prime} \mathrm{W}$ ) and another in the city of Serra de Talhada, Pernambuco state ( $7^{\circ} 59^{\prime} 9^{\prime \prime}$ S, $\left.38^{\circ} 17^{\prime} 45^{\prime \prime} \mathrm{W}\right)$, which were collected in September and October 2013.

After collection, the fruits were manually opening to obtain seeds. Any damaged and malformed seeds were discarded. They were then homogenized in terms of size, by using a mesh sieve with a diameter $\geq 2 \mathrm{~mm}$ and $\geq 4 \mathrm{~mm}$, respectively, and placed in plastic containers in an air-conditioned room at $25.5^{\circ} \mathrm{C}$ and $58 \% \mathrm{RH}$, for 12 months. 


\subsection{Accelerated aging (traditional method and saturated $\mathrm{NaCl}$ solution)}

The assays were carried out in a completely randomized design in a $2 \times 2 \times 5$ factorial scheme, for investigation of two methods (water and saturated $\mathrm{NaCl}$ solution), seeds from two geographic regions and five aging periods ( $0 \mathrm{~h}, 24 \mathrm{~h}, 48 \mathrm{~h}, 72 \mathrm{~h}$ and $96 \mathrm{~h}$ ).

Seeds from both regions were submitted to the accelerated aging test (traditional method), in which Gerbox-type transparent plastic boxes were used as individual compartments (small chambers) that contained interior supports coupled to aluminum screens (Marcos Filho, 1999).

As the E. spectabile seeds are very small, a piece of tulle tissue was laid over each aluminum screen to prevent the seeds from falling into the water. Approximately $0.5 \mathrm{~g}$ of seed were distributed to form a uniform layer, which filled the entire screen. Forty milliliters of distilled water were previously added into the boxes, which were then capped and kept in a Biochemical Oxygen Demand (BOD) chamber at $41{ }^{\circ} \mathrm{C}$ for $24 \mathrm{~h}, 48 \mathrm{~h}, 72 \mathrm{~h}$ and $96 \mathrm{~h}$.

The accelerated aging test with saturated $\mathrm{NaCl}$ solution was performed in a similar way to the traditional procedure, but instead of water, $40 \mathrm{~mL}$ saturated $\mathrm{NaCl}$ solution was added into each plastic box. The solution was prepared with $40 \mathrm{~g} \mathrm{NaCl}$ in $100 \mathrm{~mL}$ distilled water, establishing an environment with 76\% RH (Jianhua \& McDonald, 1997).

To evaluate the physiological potential of seeds from each geographic region, before and after the periods of traditional accelerated aging and with a saturated $\mathrm{NaCl}$ solution, the following tests were conducted:

Determination of water content of seeds: Based on the gravimetric technique (Brasil, 2009), $0.4 \mathrm{~g}$ of seeds per treatment was oven-dried at $105^{\circ} \mathrm{C} \pm 3^{\circ} \mathrm{C}$ for $24 \mathrm{~h}$, and the results were expressed as a percentage of the wet basis.

Germination test: Four replicates of 50 seeds were distributed in Gerbox plastic boxes, on two sheets of blotting paper properly sterilized in an oven at $105^{\circ} \mathrm{C}$ for $2 \mathrm{~h}$ and moistened with distilled water equivalent to 2.5 times the dry paper mass (Brasil, 2009).

The boxes were kept inside plastic bags, under continuous lighting in an air-conditioned room at $25{ }^{\circ} \mathrm{C}$ and $45.37 \% \mathrm{RH}$, with daily monitoring by using a digital thermo-hygrometer. Normal seedlings were those that had developed primary root and total expansion of the cotyledonary sheath at the 15th day after the test installation. The results were expressed as a percentage of normal seedlings.

Index of germination speed: Daily counts of normal seedlings were recorded from the test installation until the 15th day, according to Maguire (1962).

Mean germination time: In conjunction with the germination test, the mean germination time was calculated according to Labouriau and Valadares (1976), and the results were expressed in days.

Data were submitted to analysis of variance by the F-test and means were compared by Tukey's test at 5\% probability level, using Sisvar software (Ferreira, 2011).

\section{RESULTS AND DISCUSSION}

E. spectabile seeds evaluated in this study showed no initial differences in the water content. However, there was a significant difference between the recorded water contents when considering the geographical region in which the seeds were collected, regardless of whether the seeds were aged with water or with saturated $\mathrm{NaCl}$ solution. However, the values were within the acceptable limits, according to Marcos Filho (1999) (Table 1).

Table 1. Water content of Encholirium spectabile Mart. ex Schult. \& Schult. f. seeds from two geographic regions, before and after the traditional accelerated aging test with water ( $100 \%$ relative humidity) and saturated $\mathrm{NaCl}$ solution (76\% relative humidity) at $41^{\circ} \mathrm{C}$.

\begin{tabular}{ccccc} 
& \multicolumn{4}{c}{ Geographic region } \\
\cline { 2 - 5 } Aging period $(h)$ & \multicolumn{2}{c}{ Graça-CE } & \multicolumn{2}{c}{ Serra Talhada-PE } \\
\cline { 2 - 5 } & $\mathbf{H}_{2} \mathbf{O}$ & $\mathrm{NaCl}$ & $\mathrm{H}_{2} \mathbf{O}$ & $\mathrm{NaCl}$ \\
\hline 0 & $9.61 \mathrm{Ad}$ & $10.77 \mathrm{Ab}$ & $8.78 \mathrm{Ac}$ & $9.17 \mathrm{Ab}$ \\
24 & $32.19 \mathrm{Ac}^{*}$ & $11.08 \mathrm{Bb}_{\star}^{*}$ & $25.36 \mathrm{Ab}^{*}$ & $19.31 \mathrm{Ba}^{*}$ \\
48 & $32.52 \mathrm{Abc}^{*}$ & $21.89 \mathrm{Ba}_{*}^{*}$ & $29.24 \mathrm{Aa}^{*}$ & $19.28 \mathrm{Ba}_{\star}^{*}$ \\
\hline
\end{tabular}


Table 1. Continued...

\begin{tabular}{|c|c|c|c|c|}
\hline \multirow{3}{*}{ Aging period (h) } & \multicolumn{4}{|c|}{ Geographic region } \\
\hline & \multicolumn{2}{|c|}{ Graça-CE } & \multicolumn{2}{|c|}{ Serra Talhada-PE } \\
\hline & $\mathrm{H}_{2} \mathrm{O}$ & $\mathrm{NaCl}$ & $\mathrm{H}_{2} \mathrm{O}$ & $\mathrm{NaCl}$ \\
\hline 72 & $35.38 \mathrm{Aa}^{\star}$ & $21.63 \mathrm{Ba}^{*}$ & $30.10 \mathrm{Aa}^{*}$ & $18.99 \mathrm{Ba}_{\star}^{*}$ \\
\hline 96 & $34.84 \mathrm{Aab}^{*}$ & $12.42 \mathrm{Bb}_{\star}^{*}$ & $29.59 \mathrm{Aa}^{*}$ & $18.86 \mathrm{Ba}_{\star}^{*}$ \\
\hline $\mathrm{CV}(\%)$ & & & & \\
\hline
\end{tabular}

Means followed by the same lowercase letters in the column and uppercase letters in the row, by geographical region, do not differ by Tukey's test $(\mathrm{P} \leq 0.05) .{ }^{*}$ in the line indicates the difference between geographical regions for the method with water, and ${ }^{*}$ for the method with saturated $\mathrm{NaCl}$ solution, in each aging period. $\mathrm{CV}$ : coefficient of variation.

When considering the type of aging technique used, seeds from both geographic regions obtained a higher water content when they were submitted to the traditional accelerated aging test with water. This result was already predictable since the $\mathrm{NaCl}$ solution reduces the intensity with which seeds absorb water, corroborating the findings of Tunes et al. (2012) and Radke et al. (2016), who observed the same trend with Oryza sativa L. and Coriandrum sativa L. seeds, respectively. There was also an increase in the water content as a function of the aging exposure time of the seeds from both regions' tests (Table 1).

Seeds from Graça-CE were less vigorous than those from Serra Talhada-PE before the aging test, as well as when aged for $96 \mathrm{~h}$ by both methods (water and saturated $\mathrm{NaCl}$ solution) (Table 2). This result was justified by the decrease in the mean value of germination after aging for $96 \mathrm{~h}$ in comparison to the other aging periods, possibly due to a more intense deterioration of the seeds relative to those aged for shorter periods.

Regarding the aging method adopted (Table 2), the geographic region of the seeds led to a difference in the germination when aged for $72 \mathrm{~h}$. In the accelerated aging test with water, the germination was higher for the seeds from Graça-CE, whereas in the aging test with $\mathrm{NaCl}$ solution, the highest percentage of germination was recorded in seeds from Serra Talhada-PE. Similar results were found in Mabea fistulifera Mart. seeds aged in saline solution at $41^{\circ} \mathrm{C}$ for $72 \mathrm{~h}$ (Gomes \& Lopes, 2017).

For the seeds harvested in the city of Graça-CE, the germination speed index differed significantly between the accelerated aging methods adopted when the seeds were aged for $24 \mathrm{~h}, 48 \mathrm{~h}$ and $72 \mathrm{~h}$. Regarding the seeds harvested in Serra Talhada-PE, the type of aging procedure influenced the germination rate when the seeds were in conditions of high temperature and humidity for $24 \mathrm{~h}$ and $72 \mathrm{~h}$ (Table 3 ).

Table 2. Germination (\%) of Encholirium spectabile Mart. ex Schult. \& Schult. f. seeds from two geographic regions, before and after traditional accelerated aging methods with water (100\% relative humidity) and saturated $\mathrm{NaCl}$ solution (76\% relative humidity) at $41^{\circ} \mathrm{C}$.

\begin{tabular}{|c|c|c|c|c|}
\hline \multirow{3}{*}{ Aging period (h) } & \multicolumn{4}{|c|}{ Geographic region } \\
\hline & \multicolumn{2}{|c|}{ Graça-CE } & \multicolumn{2}{|c|}{ Serra Talhada-PE } \\
\hline & $\mathrm{H}_{2} \mathrm{O}$ & $\mathrm{NaCl}$ & $\mathrm{H}_{2} \mathrm{O}$ & $\mathrm{NaCl}$ \\
\hline 0 & $61.50 \mathrm{Ab}^{\star}$ & $59.50 \mathrm{Ad}_{\star}^{\star}$ & $86.00 \mathrm{Aab}^{\star}$ & $85.50 \mathrm{Aa}_{\star}^{*}$ \\
\hline 24 & $86.50 \mathrm{Aa}$ & $90.50 \mathrm{Aa}$ & $82.50 \mathrm{Bb}$ & $93.50 \mathrm{Aa}$ \\
\hline 48 & $87.50 \mathrm{Aa}$ & $81.50 \mathrm{Aab}$ & $85.00 \mathrm{Aab}$ & $88.00 \mathrm{Aa}$ \\
\hline 72 & $87.00 \mathrm{Aa}^{*}$ & $73.00 \mathrm{Bbc}_{\star}^{\star}$ & $75.00 \mathrm{Bb}^{*}$ & $92.00 \mathrm{Aa}_{\star}^{\star}$ \\
\hline 96 & $51.00 \mathrm{Bb}^{*}$ & $66.00 \operatorname{Acd}_{\star}^{\star}$ & $95.00 \mathrm{Aa}^{*}$ & $90.50 \mathrm{Aa}_{\star}^{\star}$ \\
\hline CV (\%) & & & & \\
\hline
\end{tabular}

Means followed by the same lowercase letters in the column and uppercase letters in the row, by geographical region, do not differ by Tukey's test $(\mathrm{P} \leq 0.05) .{ }^{*}$ in the line indicates the difference between geographical regions for the method with water, and ${ }^{* *}$ for the method with saturated $\mathrm{NaCl}$ solution, in each aging period. $\mathrm{CV}$ : coefficient of variation. 
Table 3. Germination speed index of Encholirium spectabile Mart. ex Schult. \& Schult. f. seeds from two geographic regions, before and after traditional accelerated aging methods with water ( $100 \%$ relative humidity) and saturated $\mathrm{NaCl}$ solution ( $76 \%$ relative humidity) at $41^{\circ} \mathrm{C}$.

\begin{tabular}{|c|c|c|c|c|}
\hline \multirow{3}{*}{ Aging period (h) } & \multicolumn{4}{|c|}{ Geographic region } \\
\hline & \multicolumn{2}{|c|}{ Graça-CE } & \multicolumn{2}{|c|}{ Serra Talhada-PE } \\
\hline & $\mathrm{H}_{2} \mathrm{O}$ & $\mathrm{NaCl}$ & $\mathrm{H}_{2} \mathrm{O}$ & $\mathrm{NaCl}$ \\
\hline 0 & $3.19 \mathrm{Bb}^{*}$ & $4.21 \mathrm{Ab}_{\star}^{\star}$ & $6.87 \mathrm{Aab}^{*}$ & $6.97 \mathrm{Aa}_{\star}^{\star}$ \\
\hline 24 & $6.98 \mathrm{Aa}^{*}$ & $5.38 \mathrm{Ba}_{\star}^{\star}$ & $6.11 \mathrm{Bb}^{*}$ & $6.95 \mathrm{Aa}_{\star}^{\star}$ \\
\hline 48 & $6.97 \mathrm{Aa}$ & $5.25 \mathrm{Ba} *$ & $6.53 \mathrm{Aab}$ & $7.11 \mathrm{Aa} *$ \\
\hline 72 & $7.12 \mathrm{Aa}^{*}$ & $5.31 \mathrm{Ba}_{\star}^{*}$ & $6.10 \mathrm{Bab}^{*}$ & $7.07 \mathrm{Aa} a_{\star}^{*}$ \\
\hline 96 & $3.96 \mathrm{Ab}^{*}$ & $4.42 \mathrm{Aab}_{\star}^{\star}$ & $7.14 \mathrm{Aa}^{\star}$ & $6.97 \mathrm{Aa}{ }_{\star}^{\star}$ \\
\hline CV (\%) & & & & \\
\hline
\end{tabular}

Means followed by the same lowercase letters in the column and uppercase letters in the row, by geographical region, do not differ by Tukey's test $(\mathrm{P} \leq 0.05) .{ }^{*}$ in the line indicates the difference between geographical regions for the method with water, and ${ }^{* *}$ for the method with saturated $\mathrm{NaCl}$ solution, in each aging period. $\mathrm{CV}$ : coefficient of variation.

There was no significant difference between aging periods for E. spectabile seeds from Serra Talhada-PE exposed to the saturated $\mathrm{NaCl}$ solution (Table 3). However, it is important to emphasize that these seeds provided higher germination rates than those observed in seeds from Graça-CE, under the same aging conditions.

Instead of intensifying the deteriorative process of seeds harvested in Graça-CE, accelerated aging with water favored the germination and seedlings uniformity during $24 \mathrm{~h}, 48 \mathrm{~h}$ and $72 \mathrm{~h}$. Namely, during such periods, the conditions of high temperature and $\mathrm{RH}$ provided physiological conditioning of the seeds (Tables 2 and 3). Seed reinvigoration due to physiological conditioning treatments, i.e., seed hydration without protrusion of the primary root, may reflect an increased rate and uniformity of seedling emergence (Khan, 1992).

Periods of accelerated aging, regardless of the technique employed, did not influence the germination time of E. spectabile seeds from both geographic regions. However, when not aged, the seeds harvested in Graça-CE took comparatively longer to germinate and to yield normal seedlings (Table 4).

Table 4. Average germination time of Encholirium spectabile Mart. ex Schult. \& Schult. f. seeds from two geographic regions, before and after traditional accelerated aging methods with water ( $100 \%$ relative humidity) and saturated $\mathrm{NaCl}$ solution ( $76 \%$ relative humidity) at $41^{\circ} \mathrm{C}$.

\begin{tabular}{|c|c|c|c|c|}
\hline \multirow{3}{*}{ Aging period (h) } & \multicolumn{4}{|c|}{ Geographic region } \\
\hline & \multicolumn{2}{|c|}{ Graça-CE } & \multicolumn{2}{|c|}{ Serra Talhada-PE } \\
\hline & $\mathrm{H}_{2} \mathrm{O}$ & $\mathrm{NaCl}$ & $\mathrm{H}_{2} \mathrm{O}$ & $\mathrm{NaCl}$ \\
\hline 0 & $2.62 \mathrm{Ab}^{\star}$ & $1.93 \mathrm{Ba}_{\star}^{\star}$ & $1.59 \mathrm{Aa}^{\star}$ & $1.55 \mathrm{Aa}_{\star}^{\star}$ \\
\hline 24 & $1.56 \mathrm{Ba}$ & $2.14 \mathrm{Aa}_{\star}^{\star}$ & $1.75 \mathrm{Aa}$ & $1.74 \mathrm{Aa}_{\star}^{\star}$ \\
\hline 48 & $1.60 \mathrm{Ba}$ & $1.92 \mathrm{Aa}_{\star}^{\star}$ & $1.67 \mathrm{Aa}$ & $1.56 \mathrm{Aa}_{\star}^{\star}$ \\
\hline 72 & $1.65 \mathrm{Aa}$ & $1.76 \mathrm{Aa}$ & $1.55 \mathrm{Aa}$ & $1.67 \mathrm{Aa}$ \\
\hline 96 & $1.53 \mathrm{Ba}$ & $2.09 \mathrm{Aa}_{\star}^{\star}$ & $1.71 \mathrm{Aa}$ & $1.66 \mathrm{Aa}_{\star}^{\star}$ \\
\hline CV (\%) & & & & \\
\hline
\end{tabular}

Means followed by the same lowercase letters in the column and uppercase letters in the row, by geographical region, do not differ by Tukey's test $(\mathrm{P} \leq 0.05) .{ }^{*}$ in the line indicates the difference between geographical regions for the method with water, and ${ }^{* *}$ for the method with saturated $\mathrm{NaCl}$ solution, in each aging period. $\mathrm{CV}$ : coefficient of variation. 
In determining the influence of the origin of the seeds, overall, the average germination times indicated that the seeds harvested in Serra Talhada-PE were the most vigorous, regardless of the accelerated aging test (water versus saturated $\mathrm{NaCl}$ ). However, the traditional assay (water) contributed to reducing the average germination time of seeds harvested in Graça-CE (Table 4), showing that there was a significant improvement in the physiological potential of E. spectabile seeds of this region.

These results indicate that the germinative behavior observed after exposure of E. spectabile seeds to high temperature and $\mathrm{RH}$ by the traditional accelerated aging test or with saturated $\mathrm{NaCl}$ solution may be related to the strategies used by species to survive potential environmental pressures, such as high temperatures and water deficit (Figueiredo et al., 2014). It is noteworthy that the species grows fully exposed to the sun on rock outcrops, and germination occurs most expressively after the first rains, that is, under high humidity (Ramalho et al., 2004).

Thus, it should be considered that a stress vigor test can provide deleterious conditions for a particular group of seeds (e.g., cultivated species). However, for seeds from species that have not been domesticated or that germinate in nature under similar conditions to those used in a given stress test, it can be seen that instead of being stressed, the seed may benefit from such conditions, resulting in enhanced germination and vigor.

\section{CONCLUSIONS}

Encholirium spectabile seeds presented different levels of physiological potential by the accelerated aging test, which in turn provided the reinvigoration of seeds harvested in the city of Graça-CE, when using the traditional method with water.

\section{ACKNOWLEDGEMENTS}

The authors thank the Coordination for the Improvement of Higher Education Personnel (Capes) for the concession of scholarship and the Postgraduate Program in Vegetal Production of Federal Rural University of Pernambuco/Academic Unit of Serra Talhada (UFRPE/UAST).

\section{SUBMISSION STATUS}

Received: 7 Apr., 2017

Accepted: 31 Jul., 2018

\section{CORRESPONDENCE TO}

\section{Ariana Veras de Araújo}

Universidade Federal do Ceará (UFC),

Departamento de Fitotecnia,

Av. Humberto Monte, s/n, Campus do Pici, CEP 60130-240, Fortaleza, CE, Brasil e-mail: ariana.veras@hotmail.com

\section{REFERENCES}

Alves CZ, Godoy AR, Candido ACS, Oliveira NC. Qualidade fisiológica de sementes de jiló pelo teste de envelhecimento acelerado. Ciência Rural 2012; 42(1): 58-63. 10.1590/S0103-84782012000100010

Alves CZ, Sá ME. Adequação da metodologia do teste de envelhecimento acelerado em sementes de rúcula. Semina: Ciências Agrárias 2012; 33(1): 2789-2798. 10.5433/1679-0359.2012v33Supl1p2789

Araújo ER, Andrade LA, Rêgo ER, Gonçalves EP, Araújo E. Qualidade fisiológica e sanitária de sementes de aroeira produzidas no estado da Paraíba. Agropecuária Técnica 2013 [cited 2019 Aug. 7]; 34(1): 9-20. Available from: https://bit.ly/2OLc62D

Bessa MN. A macambira (Bromelia forrageira). 2 ed. Natal: Emparn; 1982.

Brasil. Regras para análise de sementes. Brasília, DF: Ministério da Agricultura, Pecuária e Abastecimento; 2009.

Carvalho KIM, Fernandes HB, Machado FDF, Oliveira IS, Oliveira FA, Nunes PHM et al. Antiulcer activity of ethanolic extract of Encholirium spectabile Mart. ex Schult \& Schult f. (Bromeliaceae) in rodents. Biological Research 2010; 43(4): 459-465. /S0716-97602010000400011

Ferreira DF. Sisvar: a computer statistical analysis system. Ciência e Agrotecnologia 2011; 35(6): 1039-1042. 10.1590/ S1413-70542011000600001

Ferreira RA, Oliveira LM, Carvalho D, Oliveira AF, Gemaque RCR. Qualidade fisiológica de sementes de Copaifera langsdorffii Desf. (Leguminosae Caesalpinioideae) envelhecidas artificialmente. Revista Ciência Agronômica 2004; 35(1): 82-86.

Figueiredo MF, Nogueira FCB, Pinheiro CL, Brito SF, Medeiros Filho S. Germination of Encholirium spectabile Mart. ex Schult. \& Schult. f. seeds in response to temperature and water stress. American Journal of Plant Sciences 2014; 5(15): 2237-2246. 10.4236/ajps.2014.515238 
Flavio JJP, Paula RC. Testes de envelhecimento aceleradoxx e de condutividade elétrica em sementes de Dictyoloma vandellianum A. Juss. Scientia Florestalis 2010; 38(87): 391-399.

Garcia LC, Nogueira AC, Abreu DCA. Influência do envelhecimento no vigor de sementes de Anadenanthera colubrina (Vellozo) Brenan - Mimosaceae. Ciência Florestal 2004; 14(1): 85-90. 10.5902/198050981784

Gomes D Jr, Lopes JC. Teste de envelhecimento acelerado para avaliar o potencial fisiológico de sementes de canudo-de-pito. Ciência Florestal 2017; 27(4): 1105-1115. 10.5902/1980509830286

Guedes RS, Alves EU, Oliveira LSB, Andrade LA, Gonçalves EP, Melo ARF. Envelhecimento acelerado na avaliação da qualidade fisiológia de sementes de Dalbergia nigra (Vell.) Fr. All. Semina: Ciências Agrárias 2011; 32(2): 443-450. 10.5433/1679-0359.2011v32n2p443

Guedes RS, Alves EU, Oliveira LSB. Teste de envelhecimento acelerado em sementes de Chorisia glaziovii (Kuntze) (Malvaceae). Bioscience Journal 2013; 29(2): 378-385.

Jianhua Z, McDonald MD. The saturated salt accelerated aging test for small-seeded crops. Seed Science and Technology 1997; 25(1): 123-131.

Khan AA. Preplant physiological seed condictioning. Horticultural Reviews 1992; 13: 131-181. 10.1002/ 9780470650509.ch4

Labouriau LG, Valadares MEB. On the germination of seeds Calotropis procera (Ait.) Ait. f. Anais da Academia Brasileira de Ciências 1976; 48(2): 263-284.

Lima CR, Bruno RLA, Silva KRG, Pacheco MV, Alves EU. Qualidade fisiológica de sementes de diferentes árvores matrizes de Poincianella pyramidalis (Tul.) L. P. Queiroz. Revista Ciência Agronômica 2014; 45(2): 370-378.

Lima JLS. Plantas forrageiras das caatingas: usos e potencialidades. Petrolina: Embrapa-Cpatsa/PNE/RBGKEW; 1996.
Maguire JD. Speed of germination-aid in selection and evaluation for seedling emergence and vigor. Crop Science 1962; 2(1): 176-177. 10.2135/cropsci1962.0011183X000200020033x

Marcos Filho J. Teste de envelhecimento acelerado. In: Krzyzanowski FC, Vieira RD, França Neto JB, editors. Vigor de sementes: conceitos e testes. Londrina: Abrates; 1999. p. 1-24.

Marcos Filho J. Fisiologia de sementes de plantas cultivadas. 2 ed. Londrina: Abrates; 2015.

Oliveira RG Jr, Souza GR, Guimarães AL, Oliveira AP, Morais ACS, Araújo EC et al. Dried extracts of Encholirium spectabile (Bromeliaceae) present antioxidant and photoprotective activities in vitro. Journal of Young Pharmacists 2013; 5(3): 102-105. 10.1016/j.jyp.2013.08.005

Radke AL, Reis BB, Gewehr E, Almeida AS, Tunes LM, Villela FA. Alternativas metodológicas do teste de envelhecimento acelerado em sementes de coentro. Ciência Rural 2016; 46(1): 95-99. 10.1590/0103-8478cr20140188

Ramalho M, Batista MA, Silva M. Xylocopa (Monoxylocopa) abbreviata Hurd \& Moure (Hymenoptera: Apidae) e Encholirium spectabile (Bromeliaceae): uma associação estreita no semi-árido do Brasil tropical. Neotropical Entomology 2004; 33(4): 417-425. 10.1590/S1519-566X2004000400004

Santos F, Trani PE, Medina PF, Parisi JJD. Teste de envelhecimento acelerado para avaliação da qualidade de sementes de alface e almeirão. Revista Brasileira de Sementes 2011; 33(2): 322-330. 10.1590/S0101-31222011000200015

Tunes LM, Tavares LC, Barros ACSA. Envelhecimento acelerado como teste de vigor para sementes de arroz. Revista de Ciências Agrárias 2012; 35(1): 120-127. 